\title{
Impact of Public Policies on Women Health in India: An Empirical Study
}

\author{
Waseem Ahmad Khan
}

Department of Economics, Aligarh Muslim University, Aligarh, Uttar Pradesh, India

Corresponding author: wkhan312@gmail.com

\begin{abstract}
An effort has been made in this study to measure the impact of public policies on women health in Indian. This Paper has been divided into three parts: first part of the study shows the trend and pattern of the public policies on women health from 2004 to 2015. Secondly, this paper explored the effectiveness of the health policies and in order to find out the effectiveness, we have used Anova with post hoc test. Lastly, we have used regression analysis to find out the impact of public policies on women health in India.
\end{abstract}

Keywords: Public Policies, Women Health, MMR, Life Expectancy

The exercise of public health has been vibrant in India and has seen many hurdles in its attempt to affect the lives of the people of this country. Since independence, major public health problems like malaria, tuberculosis, leprosy, high maternal and child mortality and recently, human immunodeficiency virus (HIV) have been focussed through a concerted action of the government. Social development coupled with scientific advances and health attention has led to a reduction in the mortality rates and birth rates. The important issues that the health systems have been facing since a long time are lack of financial and material resources, health workforce issues and the stewardship challenge of implementing pro-equity health policies in a pluralistic environment. The National Rural Health Mission (NRHM) launched by the Government of India in 2013 is a leap ahead in establishing effective integration and convergence of health services and affecting architectural correction in the health care arrangement in India. The Integrated Disease Surveillance Project was set up to launch a dedicated source of information referring to disease occurrence required for control and containment at the community level, but the rate of implementation has been sluggish. Health profiles published by the government should be used to help communities prioritize their health problems and to inform local health centres. Public health laboratories have a dependable content to defend the government's diagnostic and research actions on health hazards and threats, but are not being used efficiently. Mechanisms to monitor epidemiological challenges like mental health, occupational health and other environmental risks are still to be set in position. A well-managed system is important for successful public health outcomes. It reduces exposure to disease through enforcement of sanitary codes, e.g., water quality monitoring, slaughterhouse hygiene and food safety. But in reality a wide gap exists in the enforcement, monitoring and evaluation, resulting in a weak public health organization. This is partially due to inadequate financing for public health, lack of leadership and commitment of public health functionaries and lack of community participation. Revival of public health regulation is possible through updating and implementation of public health laws by the government, consulting stakeholders and increasing public consciousness of existing laws and their enforcement procedures. Government through ministries of health and other related ministries and agencies, plays an important role in health development, through strengthening health systems and generation of human, financial 
and other resources. This allows health organizations to accomplish their goals of improving wellness, reducing health inequalities, ensuring equity in health care financing and responding to population needs. The governments' role in health development is well documented worldwide and is illustrated by the impressive growth of health systems, initiated and supported by governments and pursued through a partnership with the private sector, non-governmental organizations and charitable institutions. The dramatic changes and challenges which took place during the final four decades of the 20th century have greatly touched and contributed towards repositioning of the government's purpose in health as well as other societal sectors.

However, the case of the health sector is distinctive from other sectors, as market forces fail to address properly the health needs of population for various reasons, leaving government with special responsibilities to address in health development. As a consequence of market failures, governments hold an obligation to intervene in society to improve both equity and efficiency, to carry out important public health purposes and to produce vital public goods which have a lot of bearing on health development. Moreover, health is perceived in the region and elsewhere, not only as a market commodity, but as a basic human need and a social right, as expressed in the constitution and signed treaties. Such commitment entails significant roles and responsibilities for governments. The discrimination against the girl child is systematic and pervasive enough to manifest in many demographic measures for the nation. For the nation as a whole as well as its rural regions, the infant mortality rate is higher for females in comparison to that of males. Usually, though not exclusively, it is in the northern and western states that the female infant mortality rates are higher, a difference of ten points between the two sexes is an alarming situation.

The infant mortality rate is slightly in favour of females in the urban regions of the nation as well. It has been noticed in the context of women's health that sustainable well-being can be brought about if strategic interventions are made at critical stages. The life cycle approach thus advocates strategic interventions in periods of early childhood, adolescence and pregnancy, with programs ranging from nutrition supplements to life skills education. Such interventions attempt to break the vicious intergenerational cycle of ill health. The vulnerability of females in India in the crucial periods of childhood, adolescence and childbearing is underscored by the country's sex wise age-specific mortality rates. From childhood till the mid-twenties, higher ratios of women die than men in the country. Poor health has repercussions not just for women, but also on their families. Women in poor health are more likely to give birth to under weight infants. They also are less likely to be able to provide food and adequate care for their kids. Lastly, a woman's health affects the household economic welfare, as a woman in poor health will be less productive. Because of the wide variation in cultures, religions, and levels of development among India's 29 states and 7 union territories, it is not surprising that women's health also varies greatly from state to state. The health of women depends on their emotional, societal and physical well-being which are determined by different social, political and economic aspects of their lives. There are several factors responsible for the current status of women in India, one is the culture itself. Women are subjected to selective malnourishment from birth. There is a strong preference for the male child in several states promoting illegal sex determination and female foeticide. This not only poses threat to the expectant mothers physical and mental health, but also imbalances the sex ratio, thereby giving rise to several other social problems.

\section{Objectives of the study}

- To find out the trend and pattern of the women health policies in India from 2004 to 2015.

- Explore the effectiveness of the women health policies in India.

- To find out the impact of public policies on women health in India.

\section{Hypotheses of the study}

- In order to attain the above objectives, we have set two null hypotheses.

- There is no significant difference between and within the health policies in India.

- There is no significant impact of public policies on women's health in India. 


\section{Analysis of Public Policies on Women Health in India}

Role of public policies on women's health is one of the major aspects towards the development of Indian economy because without sound health no one can actively participate in the economic activities. In this new era, women can play a very crucial role in transforming the economic scenario from single-digit to double-digit growth in the Indian economy. Since Independence, the role of public policies has increased in every sector of the economy. The health sector is one of the main concerns for the policymakers because they know that without improved health they cannot perform well in any area. Women health should be given prior attention while framing the public policies because if women health gets improved they will be able to take proper care of their family as well. But if we observe the actual figures since Independence, the target has not been realised in the women health sector, the reason for this is increasing population and the federal fiscal transfers from centre to state and state to districts has not reached to the lower section of the society and sometimes the case of uneven horizontal transfers has also been observed. It has been observed that many times the policies performing well discontinued or their objective got changed because of the change in the political party.

Initially, the government of India was not focussed towards the women's health, but as time passed government realized its importance and its role in the women's health sector increased. The government aimed to extend the benefits of the public policies to the weaker section of the society, but the expenditure that has been assigned as compared to the requirements of the lower section of the society was much lower. After the reform period, the role of public policies needed to be increased because as a result of liberalization and globalization of the Indian economy, the competition level has increased and we now need to compete with the world economies. For that, there is a need to improve the social status of Indian women and without good health, they cannot perform and compete efficiently. There are various types of public policies that have been included under the women's health sector with the change in the political parties, but those policies has not been working efficiently because quality that the policies are delivering is much more important than their quantity. In 2004 the concept of gender budgeting in India came into existence and so we are now able to investigate statistically women health expenditure through public policies as they now provide the year-wise statistic about different policies. Here we will try to detect how the public policies have improved their working in women health sector. Our main motive is to find out the impact of public policies on women's health. The table 3.2.1 presented below, shows the trend and the public expenditure through a different type of public policies in the sector.

The Low level public spending on health and exorbitant out of pocket expenditure by households characterize the Indian health care system. Inadequate quality of preventive care, epidemiological changes, and demographic transition has implications for higher demand of health attention in coming years. India's rank is 143 among 190 countries in terms of world health status. It has 157th position according to per capita government spending on health which is just about \$44 PPP. India's per capita health spending is 35 percent and almost one-third of China and Thailand respectively. India's per capita government expenditure is one of the lowest in the World. It is less than one -fifth of China and about 15 percent of Thailand. In this context, unprotected financial risk of health care poses serious concern which the health care system must address. There is a distinction made between health and health-related expenditure. Besides core health services, expenditure on water, sanitation, and nutrition is considered to have direct impact on health outcome. Hence, a broad definition considers expenditure on these factors also apart from the expenditure on core health to obtain a sense of standardized health maintenance. As per this definition, health expenditure comprises expenditure incurred towards curative health care services, disease prevention, reproductive and child health programs, health promotion, administration of health services, medical education, training and research, and capital investment for health purpose. The failure of public investment in health to cover the entire spectrum of healthcare needs is reflected best in the worsening situation in terms of costs of care and impoverishment due to health care costs. Services available under national programs are free to all and universally accessed with fairly 
Table 1: Public Expenditure on Women Health Policies in India (Rupees in crores)

\begin{tabular}{|c|c|c|c|c|c|c|c|c|c|c|c|c|}
\hline \multirow{2}{*}{$\begin{array}{l}\text { S. } \\
\text { No }\end{array}$} & \multirow[t]{2}{*}{ Policies } & \multicolumn{11}{|c|}{ Years } \\
\hline & & 2004-05 & $2005-06$ & 2006-07 & 2007-08 & 2008-09 & $2009-10$ & 2010-11 & 2011-12 & 2012-13 & 2013-14 & 2014-15 \\
\hline 1 & $\begin{array}{c}\text { Rural Family Welfare } \\
\text { Services }\end{array}$ & 1722.10 & 1279.85 & NA & 2041.47 & 2463.81 & 2654.41 & 2877.55 & 3661.53 & 4295.46 & 3624.00 & 3852.11 \\
\hline 2 & $\begin{array}{c}\text { Urban Family Welfare } \\
\text { Services }\end{array}$ & 121.00 & 123.05 & 69.07 & 125.14 & 166.98 & 140.73 & 157.37 & 193.43 & 221.03 & 166.17 & 177.54 \\
\hline 3 & $\begin{array}{l}\text { Reproductive and } \\
\text { Child Health Project }\end{array}$ & 485.93 & NA & NA & 5.59 & NA & NA & NA & NA & NA & NA & NA \\
\hline 4 & $\begin{array}{l}\text { Routine Immunisation } \\
\text { Programme }\end{array}$ & NA & 164.94 & 134.40 & NA & NA & NA & NA & NA & NA & NA & NA \\
\hline 5 & $\begin{array}{l}\text { Pulse Polio } \\
\text { Immunisation }\end{array}$ & NA & 822.08 & 503.52 & NA & NA & NA & NA & NA & NA & NA & NA \\
\hline 6 & IEC (RCH) & NA & 48.98 & NA & NA & NA & NA & NA & NA & NA & NA & NA \\
\hline 7 & Training $(\mathrm{RCH})$ & NA & 30.93 & NA & NA & NA & NA & NA & NA & NA & NA & NA \\
\hline 8 & $\begin{array}{l}\text { RCH-II Flexible } \\
\text { Pool (Pro-women } \\
\text { Components) }\end{array}$ & NA & NA & 1101.09 & 1546.10 & 1275.58 & 1605.32 & 1965.14 & 2410.80 & 2067.80 & 2495.24 & 2455.20 \\
\hline 9 & $\begin{array}{l}\text { Strengthening } \\
\text { of Immunisation } \\
\text { Programme \& } \\
\text { Eradication of Polio }\end{array}$ & 1017.48 & NA & NA & NA & NA & NA & NA & NA & NA & NA & NA \\
\hline 10 & $\begin{array}{l}\text { R.A.K. College of } \\
\text { Nursing }\end{array}$ & NA & 3.42 & 3.62 & NA & NA & NA & NA & NA & NA & NA & NA \\
\hline 11 & $\begin{array}{l}\text { Lady Reading Health } \\
\text { School }\end{array}$ & NA & 1.43 & 1.31 & NA & NA & NA & NA & NA & NA & NA & NA \\
\hline 12 & $\begin{array}{c}\text { Training for ANM/ } \\
\text { LHVs }\end{array}$ & NA & 60.93 & 32.85 & NA & NA & NA & NA & NA & NA & NA & NA \\
\hline 13 & $\begin{array}{l}\text { Strengthening of Basic } \\
\text { Training Schools }\end{array}$ & NA & 2.15 & 2.15 & NA & NA & NA & NA & NA & NA & NA & NA \\
\hline 14 & $\begin{array}{l}\text { Free Distribution of } \\
\text { Contraceptives }\end{array}$ & NA & 163.00 & 100.00 & NA & NA & NA & NA & NA & NA & NA & NA \\
\hline 15 & Sterilisation Beds & NA & 3.47 & 1.15 & NA & NA & NA & NA & NA & NA & NA & NA \\
\hline 16 & RCH-II Flexible Pool & 925.18 & 910.30 & 1123.17 & 1928.58 & 3066.01 & 3431.37 & 3809.50 & 4280.00 & 3857.00 & 4391.00 & 3346.52 \\
\hline 17 & $\begin{array}{l}\text { Social Marketing of } \\
\text { Contraceptives }\end{array}$ & NA & 143.00 & 22.21 & NA & NA & NA & NA & NA & NA & NA & NA \\
\hline 18 & $\begin{array}{c}\text { Integrated Child } \\
\text { Deveopment Services } \\
\text { Scheme }\end{array}$ & NA & 3325.90 & NA & NA & NA & NA & NA & NA & NA & NA & NA \\
\hline 19 & $\begin{array}{l}\text { Safdarjung Hospital \& } \\
\text { VMC, New Delhi }\end{array}$ & NA & 156.55 & 57.59 & 72.93 & 144.56 & 182.46 & 189.10 & 207.41 & 252.98 & 349.74 & 493.30 \\
\hline 20 & $\begin{array}{c}\text { Dr. RMLHospital \& } \\
\text { SPM, PGIMER, New } \\
\text { Delhi }\end{array}$ & NA & 86.60 & 29.60 & 41.15 & 62.26 & 83.87 & 96.79 & 106.10 & 124.03 & 143.05 & 170.79 \\
\hline 21 & $\begin{array}{c}\text { Kalawati Saran } \\
\text { Children's Hospital, } \\
\text { New Delhi }\end{array}$ & NA & 18.07 & 9.60 & 10.13 & NA & NA & NA & NA & NA & NA & NA \\
\hline 22 & $\begin{array}{c}\text { All India Institute of } \\
\text { Medical Sciences, New } \\
\text { Delhi }\end{array}$ & NA & 438.36 & 195.54 & 188.00 & 292.23 & 452.12 & 502.35 & 541.80 & 655.20 & 691.05 & 826.20 \\
\hline 23 & $\begin{array}{l}\text { Lady Harding Medical } \\
\text { College \& S.K. Hospital }\end{array}$ & NA & 62.19 & 59.40 & 58.64 & 91.39 & 139.88 & 130.97 & 147.75 & 143.60 & 172.05 & 201.15 \\
\hline 24 & PGIMER, Chandigarh & NA & 161.00 & 64.60 & 77.14 & 99.17 & 148.96 & 154.66 & 173.28 & 205.20 & 241.30 & 247.00 \\
\hline 25 & JIPMER, Pondicherry & NA & 84.15 & 48.85 & 102.93 & 127.84 & 148.50 & 143.64 & 135.00 & 158.09 & 213.30 & 248.40 \\
\hline
\end{tabular}




\begin{tabular}{|c|c|c|c|c|c|c|c|c|c|c|c|c|}
\hline 26 & $\begin{array}{l}\text { National Cancer } \\
\text { Control Programme }\end{array}$ & NA & 74.00 & 27.84 & 50.40 & 61.40 & 34.39 & 32.16 & 60.84 & 115.06 & 60.32 & 285.60 \\
\hline 27 & $\begin{array}{l}\text { Grants to Kasturba } \\
\text { Health Society, Wardha }\end{array}$ & NA & 13.00 & 6.76 & 7.25 & 11.07 & 14.59 & 16.69 & 20.40 & 25.50 & 25.50 & 28.33 \\
\hline 28 & Indian Nursing Council & NA & 0.50 & NA & NA & NA & NA & NA & NA & NA & NA & NA \\
\hline 29 & $\begin{array}{l}\text { National Vector Borne } \\
\text { Disease Control } \\
\text { Programme (Including } \\
\text { Filaria \& Kala Azar) }\end{array}$ & NA & 269.93 & 155.08 & 166.47 & 151.24 & 167.85 & 202.61 & 216.22 & 189.85 & 129.11 & 212.10 \\
\hline 30 & $\begin{array}{l}\text { National TB Control } \\
\text { Programme }\end{array}$ & NA & 186.00 & 80.82 & 96.12 & 98.00 & 112.41 & 126.00 & 144.00 & 200.57 & 180.00 & 230.40 \\
\hline 31 & $\begin{array}{l}\text { National Leprosy } \\
\text { Eradication } \\
\text { Programme }\end{array}$ & NA & 28.32 & 13.13 & 8.94 & 15.64 & 14.69 & 13.31 & 14.53 & 12.98 & 13.53 & 15.18 \\
\hline 32 & $\begin{array}{l}\text { National Blindness } \\
\text { Control Programme }\end{array}$ & NA & 92.28 & 60.74 & 94.52 & 137.50 & 137.50 & 143.00 & 138.60 & 132.00 & 74.14 & 88.55 \\
\hline 33 & $\begin{array}{l}\text { Development of } \\
\text { Nursing Services }\end{array}$ & NA & 15.00 & 19.00 & 13.49 & 17.10 & 1.90 & 24.70 & 25.65 & 10.45 & 4.75 & 9.50 \\
\hline 34 & $\begin{array}{l}\text { National Institute } \\
\text { of Mental Health } \\
\text { \& Neuro-Sciences, } \\
\text { Bangalore }\end{array}$ & NA & NA & 22.44 & 20.30 & 31.45 & 43.99 & 49.16 & 60.63 & 68.39 & 83.23 & 102.71 \\
\hline 35 & $\begin{array}{c}\text { All India Institute of } \\
\text { Speech \& Hearing, } \\
\text { Mysore }\end{array}$ & NA & NA & 4.36 & 4.40 & 7.23 & 10.92 & 13.74 & 16.44 & 17.21 & 38.90 & 27.20 \\
\hline 36 & $\begin{array}{c}\text { National Aids Control } \\
\text { Programme }\end{array}$ & NA & NA & 232.87 & 295.18 & 370.70 & 323.45 & 462.07 & 450.00 & 527.87 & 450.00 & 390.00 \\
\hline 37 & $\begin{array}{c}\text { Direction \& } \\
\text { Administration }\end{array}$ & NA & NA & 121.50 & 209.40 & 318.80 & 294.44 & 351.27 & 423.92 & 471.45 & 356.50 & 359.71 \\
\hline 38 & Discretionary Grant & NA & NA & 0.35 & 0.21 & 0.21 & 0.18 & 0.35 & 7.18 & 0.53 & 0.88 & 0.88 \\
\hline 39 & $\begin{array}{l}\text { National Medical } \\
\text { Library }\end{array}$ & NA & NA & 5.01 & 4.24 & 7.29 & 7.15 & 6.77 & 9.11 & 9.30 & 11.92 & 14.39 \\
\hline 40 & $\begin{array}{l}\text { Central Government } \\
\text { Health Scheme }\end{array}$ & NA & NA & 175.71 & 195.84 & 188.81 & 304.15 & 317.19 & 360.59 & 375.58 & 411.35 & 466.53 \\
\hline 41 & Contraception & NA & NA & NA & 359.40 & 396.80 & 141.50 & 188.61 & 138.38 & 113.83 & 81.83 & 76.65 \\
\hline & Total & 4271.69 & 8769.38 & 4485.34 & 7723.96 & 9603.07 & 10596.73 & 11974.7 & 13943.59 & 14250.96 & 14408.86 & 14325.94 \\
\hline
\end{tabular}

Source: Compiled by author from gender budget statements, Ministry of Women and Child Development, GOI.

NA: Not Available.

good rates of coverage. Thus, India has one of the largest programs of publicly financed ART drugs for HIV anywhere in the world. All drugs and diagnostics in all vector-borne disease programs, tuberculosis, leprosy, including rapid diagnostic kits and third generation anti-microbicidals are free and so are insecticide-treated bed nets that cover the population of whole geographies. This is true for all the immunizations and much of the pregnancy-related care. Private markets have little contribution to make in most of these areas. Even if health care costs are more impoverishing than ever before, almost all hospitalization even in public hospitals leads to catastrophic health expenditures and over 63 million individuals are confronted with poverty every year due to health care costs alone. In 2011-12, the share of out of pocket expenditure on health care as a proportion of total household monthly per capita expenditure was 6.9 percent in rural areas and 5.5 percent in urban areas. This contributed to an increasing number of families facing catastrophic expenditures due to health costs (18 percent of all households in 2011-12 as compared to 15 percent in 2004-05). Under NRHM, free care in public hospitals was extended to a select set of conditions - for pregnancy, newborn and infant 


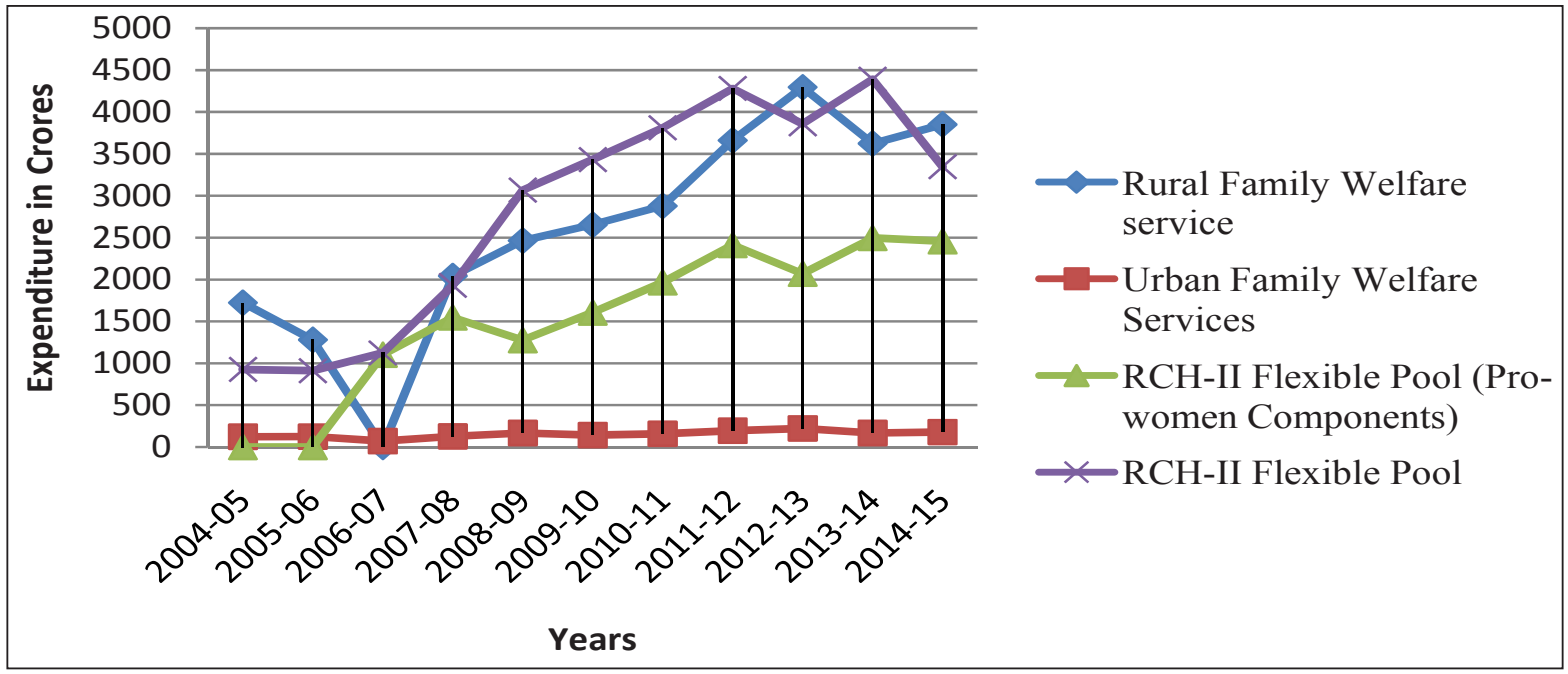

Chart 1: Expenditure on Major Women Health Policies Part A

Source: From table 1

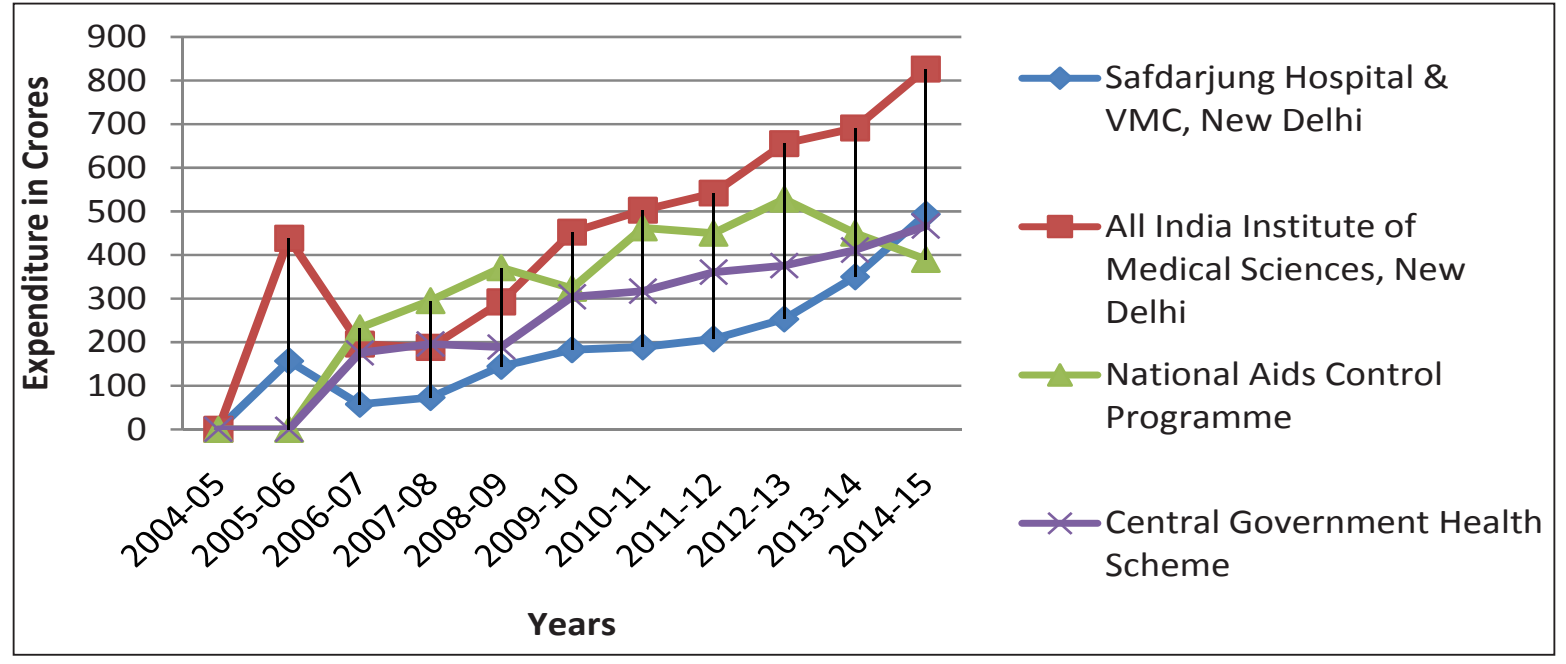

Chart 2: Expenditure on Major Women Health Policies Part B

Source: From table 1

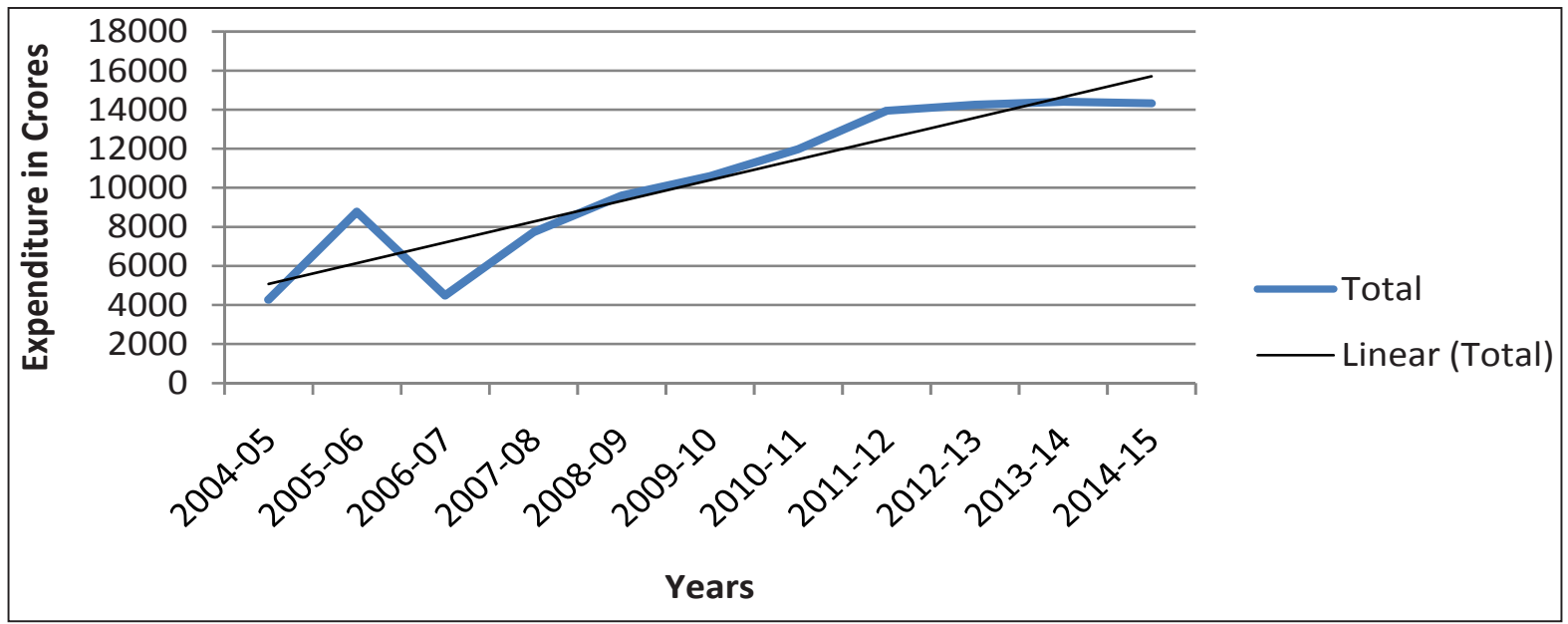

Chart 3: Total Public Expenditure on Women Health Policies in India

Source: From table 1 
care as percentage of the Janani Suraksha Yojana and Janani Shishu Suraksha Karyakram, and for disease control programs. For all other services, user fees, especially for diagnostics and "outside prescriptions for drugs" continued. Also, due to the selective approach, several essential services, especially for chronic illness was not obtainable or at best only available at overcrowded district and medical college hospitals resulting in physical and financial hardship and poor quality of care.

The Table 1 shows the government expenditure on women's health through different public policies. Most of the public policies come under the Department of Health and Family Welfare and few belong to the Ministry of Women and Child Development. In this table there are more than forty public policies related to women's health in which few of them are diversified in nature in the sense that they are meant for different health problems like health promotion, administration of health services, medical education, training and research, and capital investment for health purpose etc. whereas few of them are meant especially for the health purposes. Since half of the Indian population is comprised of females and most of the health problem in India is associated with women only, there is a need to spend more on women health issues but the above table depicts a totally different pattern of policies expenditure. The expenditure through the public policies has not been consistent and most of the public policies that started with the specific aim of women health are now discontinued. In the year 2006-07 gender budget statement was divided into two parts i.e. A and B which led to the diversification of the expenditure and almost all the policies spent some amount on women health. The first part of the gender budget statement was related to the 100 percent women specific expenditure policies whereas second part shows 30 percent women specific expenditure policies. Till then most of the expenditure on health policies came through part $B$, but in this year, part $A$ also played a very important role in women health sphere. We can also see from the table that the problems in the women health sector arise mainly from the specification of the expenditure. The government of India at centre level play its role very cleverly by spending all the women expenditure under 30 percent specific portion of the gender budget statement. We are trying to say that instead of spending more on the unspecific part, the government should try to spend more on the specific public policies. If we see from the above table the specific public policies shows insignificant expenditure during the years, trend of the public policies expenditure goes under the unspecific part of the gender budget statements and the situation of the Indian women got worsened because major part of the income they receive gets spend on health and sometimes even cost of health services surpasses their daily wages so there is a need to show more concern towards women health through public policies.

The charts are drawn on the basis of the health expenditure during the period of the study. There are forty-one policies on women health, but the charts that we drew is only for those eight policies which have shown a continuous rise in the expenditure during the period of study. The policies are divided into two parts $\mathrm{A}$ and $\mathrm{B}$ where both the parts have an equal number of policies and the last chart shows the total health expenditure pattern during the years with the trend line. From the above charts, we can understand the condition of Government expenditure on health policies in Gender budget statements during the period. Part A clearly shows that the focus is more on the four major policies. Rural Family Welfare Service and $\mathrm{RCH}$ Flexible pool have played a very important role during the years, but as we see in the chart, expenditure of RFWS in 2006-07 has become zero; the reason is a shift in the expenditure from RFWS to $\mathrm{RCH}$ flexible pool (pro women components).

Another important aspect to be focussed is that the difference between the RFWS and UFWS shows the vast gap which means that the policymakers of our country have been giving prime focus towards the RFWS and the expenditure on the UFWS seems to be constant during the years. We know that the problem is much elevated in case of rural women because of the unavailability and lack of awareness of health facilities. So there is a need to improve women health facilities in the rural areas through the public policies and make people well aware of them. The pattern of the policies expenditure has shown a positive trend in part $A$. In part $B$ there are four policies with the minimum level of expenditure. If we compare the expenditure level in both the parts a wide gap can 
be observed. The expenditure on women health in part B shows the biases of the policymakers as most of the expenditure is in favour of the capital state of the country which forces people to move from the non-beneficiary state to the beneficiary state for getting the health benefits. The expenditure on the women's health in gender budget statement has not shown much diversification and also the level of expenditure has been quite insufficient to cater the needs of all the states. The chart shows total expenditure with the trend line that shows how women health expenditure moved in an upward direction during the years. Our data shows the bestfitted trend line if we ignore two values in our data.

\section{Comparisons between and within the Major Health Policies in India}

In this part of the study, we will be differentiating between the policies and detecting the efficiency of these policies. There are forty-one policies related to women health but we have selected few policies on the basis of the expenditure during the period of the study. We have identified twelve major policies that have shown a continuous progress in expenditure on women health. The statistic that we are using for the comparison is the analysis of variance (ANOVA) with Post Hoc Test (Games Howell) and the result is Table 2.

On the basis of above tables, We can easily differentiate between the policies and determine that which has been the most effective policy for women's health during the years as far as expenditure is concerned. Before getting into the detail we should first discuss the usefulness of this statistics in our study. Looking at the nature of the data we have different policies with an equal number of observations which would enable us to do multiple comparisons. Coming to the Table 2, it is important to note that higher the mean value better our result will be considered. Now, there are three policies namely Rural Family Welfare Service, Reproductive and Child Health II (pro women components) and Reproductive and Child Health II flexible pool which have shown high mean value with a low level of standard error with their value resting between the lower and the upper limit. There are few other policies on women's health whose mean value is in between 72 to 450 which is quite low if we compare it with the above three policies but it doesn't mean that these policies

Table 2: Result of Descriptive Statistics

\begin{tabular}{|c|c|c|c|c|c|c|c|c|}
\hline \multirow{2}{*}{ POLICIES } & \multirow{2}{*}{$\mathbf{N}$} & \multirow{2}{*}{ Mean } & \multirow{2}{*}{$\begin{array}{c}\text { Std. } \\
\text { Deviation }\end{array}$} & \multirow{2}{*}{ Std. Error } & \multicolumn{2}{|c|}{$\begin{array}{l}95 \% \text { Confidence } \\
\text { Interval for Mean }\end{array}$} & \multirow{2}{*}{ Min. } & \multirow{2}{*}{ Max. } \\
\hline & & & & & $\begin{array}{l}\text { Lower } \\
\text { Bound }\end{array}$ & $\begin{array}{l}\text { Upper } \\
\text { Bound }\end{array}$ & & \\
\hline Rural Family Welfare Services & 11 & 2588.3900 & 1276.72650 & 384.94752 & 1730.6735 & 3446.1065 & .00 & 4295.46 \\
\hline Urban Family Welfare Services & 11 & 151.0464 & 41.35560 & 12.46918 & 123.2633 & 178.8294 & 69.07 & 221.03 \\
\hline $\begin{array}{l}\text { Reproductive and child health II } \\
\text { (pro-women Components) }\end{array}$ & 11 & 1538.3882 & 893.18079 & 269.30414 & 938.3412 & 2138.4352 & .00 & 2495.24 \\
\hline $\begin{array}{l}\text { Reproductive and child health II } \\
\text { flexible pool }\end{array}$ & 11 & 2824.4209 & 1351.90907 & 407.61592 & 1916.1960 & 3732.6458 & 910.30 & 4391.00 \\
\hline $\begin{array}{l}\text { Safdarjung hospital and VMC, New } \\
\text { Delhi }\end{array}$ & 11 & 191.5109 & 138.68359 & 41.81468 & 98.3420 & 284.6798 & .00 & 493.30 \\
\hline $\begin{array}{l}\text { All India Institute of Medical } \\
\text { Science, New Delhi }\end{array}$ & 11 & 434.8045 & 247.24313 & 74.54661 & 268.7043 & 600.9047 & .00 & 826.20 \\
\hline National cancer control programme & 11 & 72.9100 & 76.45243 & 23.05128 & 21.5486 & 124.2714 & .00 & 285.60 \\
\hline $\begin{array}{l}\text { National vector borne disease } \\
\text { control programme (including } \\
\text { Filaria and Kalaazar) }\end{array}$ & 11 & 169.1327 & 68.19640 & 20.56199 & 123.3178 & 214.9477 & .00 & 269.93 \\
\hline National TB control programme & 11 & 132.2109 & 65.31037 & 19.69182 & 88.3348 & 176.0870 & .00 & 230.40 \\
\hline National Aid control programme & 11 & 318.3764 & 178.22875 & 53.73799 & 198.6407 & 438.1121 & .00 & 527.87 \\
\hline Central government health scheme & 11 & 254.1591 & 156.64371 & 47.22986 & 148.9244 & 359.3938 & .00 & 466.53 \\
\hline Contraception programme & 11 & 136.0909 & 135.33815 & 40.80599 & 45.1695 & 227.0123 & .00 & 396.80 \\
\hline Total & 132 & 734.2867 & 1125.37623 & 97.95143 & 540.5155 & 928.0580 & .00 & 4391.00 \\
\hline
\end{tabular}

Source: Output by SPSS. 
Table 3: Test of Homogeneity of Variances

\begin{tabular}{cccc}
\hline Levene Statistic & df1 & df2 & Sig. \\
\hline 17.401 & 11 & 120 & .000 \\
\hline
\end{tabular}

Note: ${ }^{* * *}, * *, *$ refers to significance at $1 \%, 5 \%$ and $10 \%$ level respectively.

Source: Output by SPSS.

Table 4: Result of ANOVA

\begin{tabular}{cccccc}
\hline Policies & Sum of Squares & Df & Mean Square & F & Sig. \\
\hline Between Policies & $1.216 \mathrm{E} 8$ & 11 & $1.106 \mathrm{E} 7$ & 29.975 & .000 \\
Within Policies & $4.427 \mathrm{E} 7$ & 120 & 368909.462 & & \\
Total & $\mathbf{1 . 6 5 9 E 8}$ & $\mathbf{1 3 1}$ & & & \\
\hline
\end{tabular}

Note: ${ }^{* * *}, * *, *$ refers to significance at $1 \%, 5 \%$ and $10 \%$ level respectively.

Source: Output by SPSS.

Table 5: Result of Multiple Comparisons

\section{Games-Howell}

(I) Policies

(J) Policies

Mean

Difference

(I-J)

1. Rural Family Welfare Urban Family Welfare Services

Services

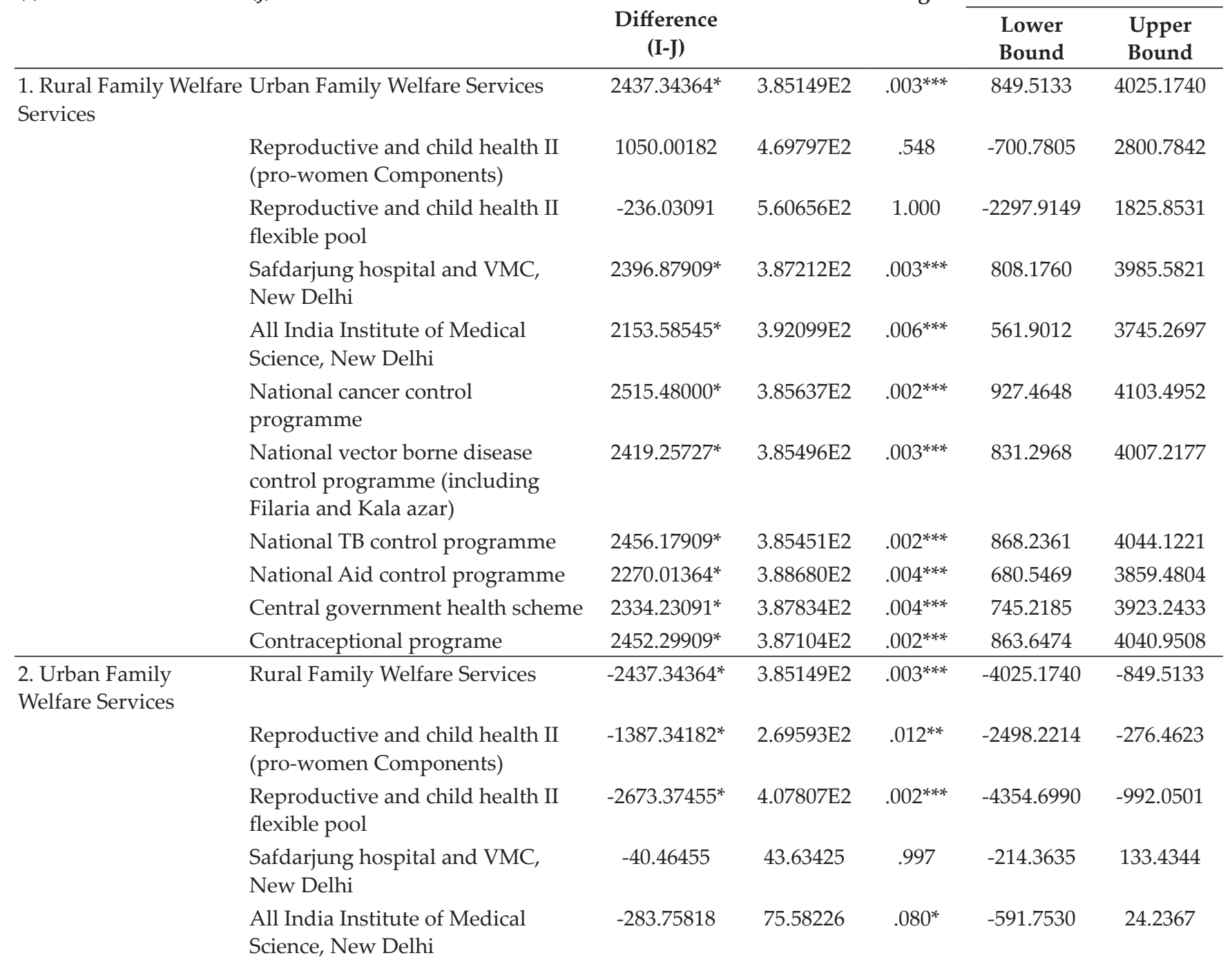

Std. Error

\section{Sig.}

95\% Confidence Interval

Lower Upper

Lower Upper

Bound

.




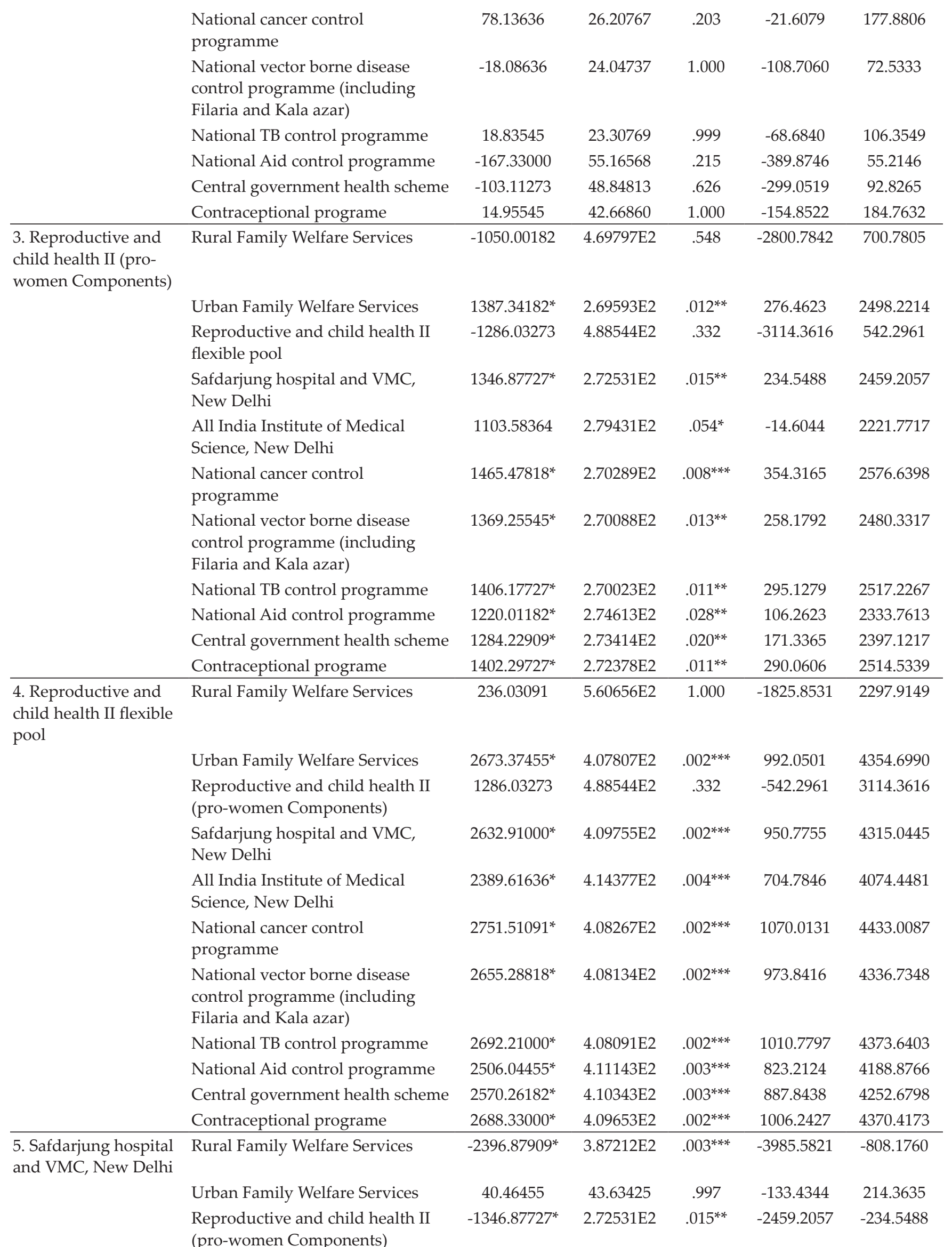




\begin{tabular}{|c|c|c|c|c|c|c|}
\hline & $\begin{array}{l}\text { Reproductive and child health II } \\
\text { flexible pool }\end{array}$ & $-2632.91000^{*}$ & 4.09755E2 & $.002^{* * *}$ & -4315.0445 & -950.7755 \\
\hline & $\begin{array}{l}\text { All India Institute of Medical } \\
\text { Science, New Delhi }\end{array}$ & -243.29364 & 85.47318 & .248 & -567.5591 & 80.9718 \\
\hline & $\begin{array}{l}\text { National cancer control } \\
\text { programme }\end{array}$ & 118.60091 & 47.74755 & .412 & -62.8187 & 300.0206 \\
\hline & $\begin{array}{l}\text { National vector borne disease } \\
\text { control programme (including } \\
\text { Filaria and Kala azar) }\end{array}$ & 22.37818 & 46.59681 & 1.000 & -156.4708 & 201.2272 \\
\hline & National TB control programme & 59.30000 & 46.21942 & .969 & -118.7753 & 237.3753 \\
\hline & National Aid control programme & -126.86545 & 68.08993 & .766 & -378.9402 & 125.2092 \\
\hline & Central government health scheme & -62.64818 & 63.08032 & .996 & -294.9418 & 169.6454 \\
\hline & Contraceptional programe & 55.42000 & 58.42599 & .997 & -159.3823 & 270.2223 \\
\hline \multirow{11}{*}{$\begin{array}{l}\text { 6. All India Institute of } \\
\text { Medical Science, New } \\
\text { Delhi }\end{array}$} & Rural Family Welfare Services & $-2153.58545^{*}$ & 3.92099E2 & $.006^{* * *}$ & -3745.2697 & -561.9012 \\
\hline & Urban Family Welfare Services & 283.75818 & 75.58226 & $.080^{*}$ & -24.2367 & 591.7530 \\
\hline & $\begin{array}{l}\text { Reproductive and child health II } \\
\text { (pro-women Components) }\end{array}$ & -1103.58364 & $2.79431 \mathrm{E} 2$ & $.054^{*}$ & -2221.7717 & 14.6044 \\
\hline & $\begin{array}{l}\text { Reproductive and child health II } \\
\text { flexible pool }\end{array}$ & $-2389.61636^{*}$ & 4.14377E2 & $.004^{* * *}$ & -4074.4481 & -704.7846 \\
\hline & $\begin{array}{l}\text { Safdarjung hospital and VMC, } \\
\text { New Delhi }\end{array}$ & 243.29364 & 85.47318 & .248 & -80.9718 & 567.5591 \\
\hline & $\begin{array}{l}\text { National cancer control } \\
\text { programme }\end{array}$ & $361.89455^{*}$ & 78.02921 & $.018^{* *}$ & 51.5832 & 672.2059 \\
\hline & $\begin{array}{l}\text { National vector borne disease } \\
\text { control programme (including } \\
\text { Filaria and Kala azar) }\end{array}$ & 265.67182 & 77.33041 & .118 & -43.8350 & 575.1786 \\
\hline & National TB control programme & 302.59364 & 77.10360 & $.057^{*}$ & -6.6755 & 611.8627 \\
\hline & National Aid control programme & 116.42818 & 91.89651 & .974 & -225.3430 & 458.1994 \\
\hline & Central government health scheme & 180.64545 & 88.24883 & .661 & -150.7109 & 512.0018 \\
\hline & Contraceptional programe & 298.71364 & 84.98427 & $.083^{*}$ & -24.3906 & 621.8178 \\
\hline \multirow{11}{*}{$\begin{array}{l}\text { 7. National cancer } \\
\text { control programme }\end{array}$} & Rural Family Welfare Services & $-2515.48000^{*}$ & 3.85637E2 & $.002^{* * *}$ & -4103.4952 & -927.4648 \\
\hline & Urban Family Welfare Services & -78.13636 & 26.20767 & 203 & -177.8806 & 21.6079 \\
\hline & $\begin{array}{l}\text { Reproductive and child health II } \\
\text { (pro-women Components) }\end{array}$ & $-1465.47818^{*}$ & $2.70289 \mathrm{E} 2$ & $.008^{* * *}$ & -2576.6398 & -354.3165 \\
\hline & $\begin{array}{l}\text { Reproductive and child health II } \\
\text { flexible pool }\end{array}$ & $-2751.51091^{*}$ & 4.08267E2 & $.002^{* * *}$ & -4433.0087 & -1070.0131 \\
\hline & $\begin{array}{l}\text { Safdarjung hospital and VMC, } \\
\text { New Delhi }\end{array}$ & -118.60091 & 47.74755 & .412 & -300.0206 & 62.8187 \\
\hline & $\begin{array}{l}\text { All India Institute of Medical } \\
\text { Science, New Delhi }\end{array}$ & $-361.89455^{*}$ & 78.02921 & $.018^{* *}$ & -672.2059 & -51.5832 \\
\hline & $\begin{array}{l}\text { National vector borne disease } \\
\text { control programme (including } \\
\text { Filaria and Kala azar) }\end{array}$ & -96.22273 & 30.88943 & .147 & -209.9502 & 17.5048 \\
\hline & National TB control programme & -59.30091 & 30.31714 & .715 & -171.0700 & 52.4682 \\
\hline & National Aid control programme & $-245.46636^{*}$ & 58.47335 & $.029^{* *}$ & -472.5574 & -18.3753 \\
\hline & Central government health scheme & -181.24909 & 52.55493 & $.098^{*}$ & -383.1003 & 20.6021 \\
\hline & Contraceptional programe & -63.18091 & 46.86673 & .958 & -240.8724 & 114.5106 \\
\hline
\end{tabular}


8. National vector Rural Family Welfare Services

$-2419.25727^{*}$

3.85496E2

$.003^{* * *}$

$-4007.2177$

$-831.2968$

borne disease control

programme (including

Filaria and Kala azar)

\begin{tabular}{|c|c|c|c|c|c|c|}
\hline \\
\hline & Urban Family Welfare Services & 18.08636 & 24.04737 & 1.000 & -72.5333 & 108.7060 \\
\hline & $\begin{array}{l}\text { Reproductive and child health II } \\
\text { (pro-women Components) }\end{array}$ & $-1369.25545^{*}$ & $2.70088 \mathrm{E} 2$ & $.013^{* *}$ & -2480.3317 & -258.1792 \\
\hline & $\begin{array}{l}\text { Reproductive and child health II } \\
\text { flexible pool }\end{array}$ & $-2655.28818^{*}$ & 4.08134E2 & $.002^{* * *}$ & -4336.7348 & -973.8416 \\
\hline & $\begin{array}{l}\text { Safdarjung hospital and VMC, } \\
\text { New Delhi }\end{array}$ & -22.37818 & 46.59681 & 1.000 & -201.2272 & 156.4708 \\
\hline & $\begin{array}{l}\text { All India Institute of Medical } \\
\text { Science, New Delhi }\end{array}$ & -265.67182 & 77.33041 & .118 & -575.1786 & 43.8350 \\
\hline & $\begin{array}{l}\text { National cancer control } \\
\text { programme }\end{array}$ & 96.22273 & 30.88943 & .147 & -17.5048 & 209.9502 \\
\hline & National TB control programme & 36.92182 & 28.47039 & .970 & -67.7646 & 141.6083 \\
\hline & National Aid control programme & -149.24364 & 57.53753 & .368 & -374.7505 & 76.2632 \\
\hline & Central government health scheme & -85.02636 & 51.51169 & .863 & -284.8328 & 114.7801 \\
\hline & Contraceptional programe & 33.04182 & 45.69381 & 1.000 & -141.9628 & 208.0464 \\
\hline 9. National TB control & Rural Family Welfare Services & $-2456.17909^{*}$ & $3.85451 \mathrm{E} 2$ & $.002^{* * *}$ & -4044.1221 & -868.2361 \\
\hline & Urban Family Welfare Services & -18.83545 & 23.30769 & .999 & -106.3549 & 68.6840 \\
\hline & $\begin{array}{l}\text { Reproductive and child health II } \\
\text { (pro-women Components) }\end{array}$ & $-1406.17727^{*}$ & 2.70023E2 & $.011^{* *}$ & -2517.2267 & -295.1279 \\
\hline & $\begin{array}{l}\text { Reproductive and child health II } \\
\text { flexible pool }\end{array}$ & $-2692.21000^{*}$ & 4.08091E2 & $.002^{* * *}$ & -4373.6403 & -1010.7797 \\
\hline & $\begin{array}{l}\text { Safdarjung hospital and VMC, } \\
\text { New Delhi }\end{array}$ & -59.30000 & 46.21942 & .969 & -237.3753 & 118.7753 \\
\hline & $\begin{array}{l}\text { All India Institute of Medical } \\
\text { Science, New Delhi }\end{array}$ & -302.59364 & 77.10360 & $.057^{*}$ & -611.8627 & 6.6755 \\
\hline & $\begin{array}{l}\text { National cancer control } \\
\text { programme }\end{array}$ & 59.30091 & 30.31714 & .715 & -52.4682 & 171.0700 \\
\hline & $\begin{array}{l}\text { National vector borne disease } \\
\text { control programme (including } \\
\text { Filaria and Kala azar) }\end{array}$ & -36.92182 & 28.47039 & .970 & -141.6083 & 67.7646 \\
\hline & National Aid control programme & -186.16545 & 57.23233 & .146 & -411.2023 & 38.8714 \\
\hline & Central government health scheme & -121.94818 & 51.17057 & .472 & -321.1442 & 77.2478 \\
\hline & Contraceptional programe & -3.88000 & 45.30890 & 1.000 & -178.0743 & 170.3143 \\
\hline 10. National Aid & Rural Family Welfare Services & $-2270.01364^{*}$ & $3.88680 \mathrm{E} 2$ & $.004^{* * *}$ & -3859.4804 & -680.5469 \\
\hline & Urban Family Welfare Services & 167.33000 & 55.16568 & .215 & -55.2146 & 389.8746 \\
\hline & $\begin{array}{l}\text { Reproductive and child health II } \\
\text { (pro-women Components) }\end{array}$ & $-1220.01182^{*}$ & 2.74613E2 & $.028^{* *}$ & -2333.7613 & -106.2623 \\
\hline & $\begin{array}{l}\text { Reproductive and child health II } \\
\text { flexible pool }\end{array}$ & $-2506.04455^{*}$ & 4.11143E2 & $.003^{* * *}$ & -4188.8766 & -823.2124 \\
\hline & $\begin{array}{l}\text { Safdarjung hospital and VMC, } \\
\text { New Delhi }\end{array}$ & 126.86545 & 68.08993 & .766 & -125.2092 & 378.9402 \\
\hline & $\begin{array}{l}\text { All India Institute of Medical } \\
\text { Science, New Delhi }\end{array}$ & -116.42818 & 91.89651 & .974 & -458.1994 & 225.3430 \\
\hline & $\begin{array}{l}\text { National cancer control } \\
\text { programme }\end{array}$ & $245.46636^{*}$ & 58.47335 & $.029^{* *}$ & 18.3753 & 472.5574 \\
\hline
\end{tabular}




National vector borne disease
control programme (including
Filaria and Kala azar)
National TB control programme
Central government health scheme
Contraceptional programe

11. Central government Rural Family Welfare Services health scheme

\begin{tabular}{|c|c|c|c|c|c|}
\hline $\begin{array}{l}\text { National vector borne disease } \\
\text { control programme (including } \\
\text { Filaria and Kala azar) }\end{array}$ & 149.24364 & 57.53753 & .368 & -76.2632 & 374.7505 \\
\hline National TB control programme & 186.16545 & 57.23233 & .146 & -38.8714 & 411.2023 \\
\hline Central government health scheme & 64.21727 & 71.54321 & .998 & -199.2959 & 327.7305 \\
\hline Contraceptional programe & 182.28545 & 67.47518 & .297 & -67.8533 & 432.4242 \\
\hline Rural Family Welfare Services & $-2334.23091^{*}$ & $3.87834 \mathrm{E} 2$ & $.004^{* * *}$ & -3923.2433 & -745.2185 \\
\hline Urban Family Welfare Services & 103.11273 & 48.84813 & .626 & -92.8265 & 299.0519 \\
\hline $\begin{array}{l}\text { Reproductive and child health II } \\
\text { (pro-women Components) }\end{array}$ & $-1284.22909^{*}$ & $2.73414 \mathrm{E} 2$ & $.020^{* *}$ & -2397.1217 & -171.3365 \\
\hline $\begin{array}{l}\text { Reproductive and child health II } \\
\text { flexible pool }\end{array}$ & $-2570.26182^{*}$ & 4.10343E2 & $.003^{* * *}$ & -4252.6798 & -887.8438 \\
\hline $\begin{array}{l}\text { Safdarjung hospital and VMC, } \\
\text { New Delhi }\end{array}$ & 62.64818 & 63.08032 & .996 & -169.6454 & 294.9418 \\
\hline $\begin{array}{l}\text { All India Institute of Medical } \\
\text { Science, New Delhi }\end{array}$ & -180.64545 & 88.24883 & .661 & -512.0018 & 150.7109 \\
\hline $\begin{array}{l}\text { National cancer control } \\
\text { programme }\end{array}$ & 181.24909 & 52.55493 & $.098^{*}$ & -20.6021 & 383.1003 \\
\hline $\begin{array}{l}\text { National vector borne disease } \\
\text { control programme (including } \\
\text { Filaria and Kala azar) }\end{array}$ & 85.02636 & 51.51169 & .863 & -114.7801 & 284.8328 \\
\hline National TB control programme & 121.94818 & 51.17057 & .472 & -77.2478 & 321.1442 \\
\hline National Aid control programme & -64.21727 & 71.54321 & .998 & -327.7305 & 199.2959 \\
\hline Contraceptional programe & 118.06818 & 62.41625 & .751 & -111.9505 & 348.0868 \\
\hline Rural Family Welfare Services & $-2452.29909^{*}$ & $3.87104 \mathrm{E} 2$ & $.002^{* * *}$ & -4040.9508 & -863.6474 \\
\hline Urban Family Welfare Services & -14.95545 & 42.66860 & 1.000 & -184.7632 & 154.8522 \\
\hline $\begin{array}{l}\text { Reproductive and child health II } \\
\text { (pro-women Components) }\end{array}$ & $-1402.29727^{*}$ & $2.72378 \mathrm{E} 2$ & $.011^{* *}$ & -2514.5339 & -290.0606 \\
\hline $\begin{array}{l}\text { Reproductive and child health II } \\
\text { flexible pool }\end{array}$ & $-2688.33000^{*}$ & 4.09653E2 & $.002^{* * *}$ & -4370.4173 & -1006.2427 \\
\hline $\begin{array}{l}\text { Safdarjung hospital and VMC, } \\
\text { New Delhi }\end{array}$ & -55.42000 & 58.42599 & .997 & -270.2223 & 159.3823 \\
\hline $\begin{array}{l}\text { All India Institute of Medical } \\
\text { Science,New Delhi }\end{array}$ & -298.71364 & 84.98427 & $.083^{*}$ & -621.8178 & 24.3906 \\
\hline $\begin{array}{l}\text { National cancer control } \\
\text { programme }\end{array}$ & 63.18091 & 46.86673 & .958 & -114.5106 & 240.8724 \\
\hline $\begin{array}{l}\text { National vector borne disease } \\
\text { control programme (including } \\
\text { Filaria and Kala azar) }\end{array}$ & -33.04182 & 45.69381 & 1.000 & -208.0464 & 141.9628 \\
\hline National TB control programme & 3.88000 & 45.30890 & 1.000 & -170.3143 & 178.0743 \\
\hline National Aid control programme & -182.28545 & 67.47518 & .297 & -432.4242 & 67.8533 \\
\hline Central government health scheme & -118.06818 & 62.41625 & .751 & -348.0868 & 111.9505 \\
\hline
\end{tabular}

Note: ${ }^{* * *}, * * *$ refers to significance at $1 \%, 5 \%$ and $10 \%$ level respectively.

Source: Output by SPSS. 
do not have any impact on women's health. The researcher has arranged the policies in descending order according to their mean value which reveals their effectiveness. Later with the use of ANOVA and post hoc test, we can compare the data within the policies and between the policies.

Before making multiple comparisons between the policies we want to check the test of homogeneity of variance. Statistically, there are different types of test to determine the homogeneity of variance but we are using the Levene test for this purpose. In the Levene statistic, we are assuming our null hypothesis that the variance in the population from which samples have been taken does not significantly differ from each other. The $p$-value less than 0.05 suggest that there is no homogeneity in the variance. According to the null hypothesis, the p-value should be greater than 0.05 which proves homogeneity of variance. In our case, the p-value seems to be significant against the $\mathrm{f}$ statistic that is 17.401, it means that the assumption of the Levene test becomes violated but as we know that result of ANOVA was significant that's why we are able to move further for the multiple comparisons with assuming unequal variance. Now, for unequal variance, we have considered the Games-Howell post hoc test for the multiple comparisons. The ANOVA test found to be significant between the policies and within the policies with 95\% confidence level. These comparisons give the overall performance of the policies out of which we will discuss only those that performed well.

\section{Rural Family Welfare Service to Other Policies}

Seeing at the result we may say that this policy has shown significant differences with almost all the policies and the positive mean difference also indicate the effectiveness of this policy if we see in the descriptive statistics the mean value of this policy is second largest in the group. The mean difference of this policy seems to be insignificantly negative in comparison with RCH II flexible Pool. Whereas, if we compare it with RCH II flexible pool (pro women Components), the result obtained from the table is insignificant with positive mean differing value, because the mean value of RFWS is greater than the mean value of RCH II flexible pool (pro women Components) and both shows similar kind of expenditure pattern. Other than that if we compare it with remaining policies in the group, the p-value is significant at $95 \%$ level of confidence. According to the above analysis, the result of this policy shows significantly higher mean difference value if we compare it with other. Thus, we may conclude that keeping aside two policies i.e. $\mathrm{RCH}$ II flexible policies and RCH II flexible pool (pro women's component), RFWS has performed well as far as women health expenditure is concerned under the gender budget statements.

\section{Reproductive and Child Health II Flexible Pool to Other Policies}

The result of RCH II Flexible pool in the given table of multiple comparisons also determines how this policy has performed as compared to the other policies. If we compare the mean difference of this policy with others in the above table it comes out to be positive due to the fact that this policy has the highest mean value but mere this fact does not affirm that this policy has significant $\mathrm{p}$-value too. Again there are two policies that have insignificant p-value namely RFWS and RCH II flexible pool (pro women Components) which signifies similarity between these policies but since here we are interested in finding out the difference between the policies, we ignore these two policies. So in the end, we may conclude that this policy also performed well in terms of women health expenditure under the gender budget statements.

\section{Reproductive and Child Health II Flexible Pool (Pro Women Components) to Other Policies}

According to our result, this policy also plays a very important role in women health. The descriptive statistic of this policy shows a third largest mean value between the groups whereas if we compare its p-value with others it mostly emerges out to be significant but if we compare it with above two policies, then its p-value is insignificant. This policy also came out to be insignificant when compared with AIIMS expenditures. It means that expenditure on that policy clearly shows the difference with other policies and we may conclude that this policy performed well as far as women health expenditure is concerned with the gender budget statements.

In the above table, multiple comparisons of almost all the remaining policies came out to be insignificant. So we can say that above three policies 
Table 6: Result of Regression Model-1

\begin{tabular}{|c|c|c|c|c|c|c|}
\hline & \multirow{2}{*}{ Model } & \multicolumn{2}{|c|}{ Unstandardized Coefficients } & \multirow{2}{*}{$\frac{\text { Standardized Coefficients }}{\text { Beta }}$} & \multirow{2}{*}{$T$} & \multirow{2}{*}{ Sig. } \\
\hline & & B & Std. Error & & & \\
\hline \multirow{2}{*}{1} & (Constant) & 8.450 & .520 & & 16.263 & .000 \\
\hline & LNPEXP & -.329 & .057 & -.889 & -5.817 & .000 \\
\hline
\end{tabular}

Note: $R$ square value is 0.790 .

Source: Output by SPSS.

Table 7: Result of Regression Model-2

\begin{tabular}{|c|c|c|c|c|c|c|c|c|}
\hline & \multirow[t]{2}{*}{ Model } & \multicolumn{2}{|c|}{$\begin{array}{c}\text { Unstandardized } \\
\text { Coefficients }\end{array}$} & \multirow{2}{*}{$\begin{array}{c}\begin{array}{c}\text { Standardized } \\
\text { Coefficients }\end{array} \\
\text { Beta } \\
\end{array}$} & \multirow[t]{2}{*}{$t$} & \multirow[t]{2}{*}{ Sig. } & \multicolumn{2}{|c|}{ 95\% Confidence Interval for } \\
\hline & & B & Std. Error & & & & Lower Bound & Upper Bound \\
\hline \multirow[t]{2}{*}{2} & (Constant) & 3.800 & .074 & & 51.478 & .000 & 3.633 & 3.967 \\
\hline & LNPEXP & .045 & .008 & .879 & 5.542 & .000 & .026 & .063 \\
\hline
\end{tabular}

Note: $R$ square value is 0.773 .

Source: Output by SPSS.

are most effective in nature whereas the remaining policies also found a difference in between the groups but not as much as we got from the above three policies.

\section{Regression Analysis of Public Policies on Women Health in India}

In order to find out the impact of public expenditure on women health, we have included two dependent and one independent variable in our models. First, we will explore the impact of public expenditure on the maternal mortality rates through model 1 , the second model shows the impact of public expenditure on the life expectancy of a female at birth. Both models will be worked out separately.

Model-1,

$$
L N M M R=\alpha-\beta L N P E X P+\varepsilon
$$

Where,

LNMMR $=$ Natural Log of Maternal Mortality Ratio. LNPEXP = Natural Log of Public Expenditure.

$\alpha$ and $\beta$ are coefficients of variable and $\varepsilon$ is the error term.

From the table 6 result, we can say that there is an impact of public expenditure policies on women's health in India. The above statistics suggest that an increment in public expenditure by 1 percent will lead to a fall in MMR by 0.329 percent with
$5 \%$ significance level. The results also explore the negative relationship between the variables. Our $\mathrm{R}$ square value 0.79 suggests that our model is best fitted. We can say that if we increase the government expenditure then it will lead to decrease in the maternal mortality ratio.

\section{Model-2}

$$
L N L E F=\alpha+\beta L N P E X P+\varepsilon
$$

Where,

LNLEF $=$ Natural Log of Life Expectancy of Female. LNPEXP = Natural Log of Public Expenditure.

$\alpha$ and $\beta$ are coefficients of variable and $\varepsilon$ is the error term.

The result of model 2 in Table 7 explores the positive relationship between the two variables i.e. public expenditure and life expectancy of females at birth. The result says that if there is an increase in the public expenditure by 1 percent, it will lead to increase in the life expectancy of a female at birth by 0.045 . The $\mathrm{R}$ square value suggests us that the model 2 is best fitted with the 0.773 value. Thus, we can say that only 4.5 percent variation in the dependent variable is explained by the public spending. Definitely, there are other factors as well which are affecting the life expectancy of females at birth but a positive impact of public expenditure on our dependent variable can't be ignored. 


\section{CONCLUSION}

The two objectives set for this study are: To find out the effectiveness of women health policies in India and to discover the impact of public policies on women's health. To attain these two objectives we set two hypotheses i) There is no significant difference between and within the health policies in India and ii) There is no significant impact of public policies on women's health in India. While working on the first objective we have conducted ANOVA test whose p-value came out to be 0.000 which means that there is significant difference between and within the policies at $5 \%$ level of significance. Before making multiple comparisons, we have conducted levene test to find out the homogeneity of variance. The p-value of levene statistics occurred significant under $5 \%$ level of significance which means that the variance among the policies is unequal due to which we used Games Howell test for multiple comparisons. We have selected major policies and have done multiple comparison among them to find out their effectiveness and reached to the conclusion that among all the major policies, Rural Family Welfare Service, Reproductive and Child Health II Flexible Pool, Reproductive and Child Health II Flexible Pool (Pro-women's component) etc. are the most effective policies based on their significant values when compared with others and thus rejected the null hypothesis. The result of ANOVA and Games Howell test gave us a clear idea that there is a significant difference between and within the policies. The next objective was to find out the impact of public policies on women's health. We have used Regression analysis for that purpose and regressed public expenditure under women health policies on maternal mortality rate and life expectancy at birth using two different models. Both the regression results came out to be significant with p-value 0.000 for both the variables and coefficient -0.32 and +0.045 under $5 \%$ level of significance respectively. This result suggests that the maternal mortality rate is negatively related and life expectancy at birth has a positive relation with government expenditure on women health policies which leads to the rejection of null hypothesis thereby proving that there is a significant impact of public health policies on women's health.

\section{REFERENCES}

Meera Chatterjee, 1990. Indian Women: Their Health and Economic Productivity, World Bank Discussion Papers 109, Washington, pp. 186-199.

Jaishree Ganjiwale 2012. 'Current Health Status of Women in India - Issues and Challenges', health line, 3(2).

Arun, J.V. and Kumar, D. 2015. “Causality between Public Health Expenditure and Economic Growth in Brics Countries", International Journal of Scientific Research and Management, 3(11): 3718-3722.

Chandrasekhar, S. 2011. “Infant Mortality, Population Growth and Family Planning in India", Routledge Library Editions: Development, Routledge Publisher, New York.

Government of India 2012. Indian Public health Standards (IPHS) Guidelines for Sub-Centres, Directorate General of Health Services, Ministry of Health and Family Welfare, Govt. of India.

Husain, Z. 2011. "Health of the National Rural Health Mission", Economic and Political Weekly, XLVI(4): 53-59.

Patil, A.V., Somasundaram, K.V. and Goyal, R.C. 2002. "Current Health Scenario in Rural India", Australian Journal of Rural Health, 10: 129-135.

Perabathina, S. and Ellangovan, K. 2011. “Universal Health Coverage in Kerala through a Primary Care Pilot Project (Final Report)", Ministry of Health and Family welfare, Govt. of Kerala.

NFHS 3, retrieved from rchiips.org/NFHS/factsheet.shtml

Condition of Health retrieved from planning.up.nic.in/apd/ hdr-2006/chapter-4.pdf

Rural health Statistics, Government of India Ministry of Health and Family Welfare Statistics Division, 2015 retrieved from http://wcd.nic.in/sites/default/files/RHS_1. pdf

Rural Health Statistics 2015, Statistics Division, Ministry of Health and Family Welfare, pp.56-83 retrieved from http:// wcd.nic.in/sites/default/files/RHS_1.pdf

K.S. Jacob, 'Women's health and need for gender justice' retrieved from http://www.thehindu.com/todays-paper/ tp-opinion/Womenrsquos-health-need-for-gender-justice/ article16564920.ece

Note on 'Janani Shishu Suraksha Karyakram', retrieved from http://nhm.gov.in/janani-shishu-suraksha-karyakram. html

Free Entitlements for pregnant women, retrieved from http://vikaspedia.in/health/nrhm/national-healthprogrammes-1/janani-shishu-suraksha-karyakram

'Note on kishori shakti yojana' retrieved from http://wcd.nic. in/kishori-shakti-yojana

'An Essay on kishori shakti yojana', retrieved from http:// www.indianyojana.com/yojana-for-girls/kishori-shaktiyojana.htm 